\title{
口腔扁平上皮癌一次症例に対する頸部郭清の検討
}

\author{
楠川仁悟·亀山忠光・中村芳明 \\ 田中俊一・豊福司生*
}

\section{Evaluation of neck dissection for primary squamous cell carcinoma of the oral cavity}

\author{
Jingo Kusukawa $\cdot$ Tadamitsu Kameyama $\cdot$ Yoshiaki Nakamura \\ Shun-ichi TANaKa $\cdot$ Sisei Toyofuku*
}

\begin{abstract}
To evaluate neck dissection as an initial treatment for the control of neck metastasis, 141 patients with squamous cell carcinoma of the oral cavity who underwent neck dissection were examined.

Eleven $(31.4 \%)$ of 35 patients who underwent elective dissection had histologically involved nodes, and $60(56.6 \%)$ of 106 patients who underwent therapeutic dissection also had histological evidence of involved nodes. Thus, there were $46(32.6 \%)$ false-positive cases, 11 (7.8\%) false-negative cases, and the rate of correct diagnosis for neck metastasis was $59.6 \%$. The five-year cumulative survival for patients without neck metastasis was $85.7 \%$, and the presence of involved nodes reduced the survival rate to $60.4 \%$. Although there was no significant difference in survival rate among patients treated by radical neck dissection (RND), modified RND (mRND), and suprahyoid neck dissection (SHND), patients treated by SHND had a significantly higher incidence of recurrence in the ipsilateral neck than did those treated by RND/mRND. We also found a high prevalence of neck metastases in levels I III for SCCs of the oral cavity.
\end{abstract}

Key words: oral cavity（口腔), squamous cell carcinoma（扁平上皮癌）, neck metastasis (頸部転 移), neck dissection (頸部郭清術), initial treatment ( 1 次治療)

緒 言

口腔癌治療において, 原発巣とともに頸部リンパ節 の制御は重要な課題であり,このため頸部郭清術は欠 くことができない治療法となっている. 今回われわれ は, 口腔扁平上皮癌一次症例に対する初回治療として

久留米大学医学部口腔外科学教室

(主任 : 亀山忠光教授)

*聖マリア病院歯科口腔外科

（医長：豊福司生）

Department of Oral and Maxillofacial Surgery, Kurume University School of Medicine (Chief: Prof. Tadamitsu Kameyama)

* Department of Dentistry and Oral Surgery, St. Mary Hospital (Chief: Dr. Sisei Toyofuku)

受付日: 平成 8 年 7 月 1 日
頸部郭清術を施行した症例について,リンパ節転移の 様相, 頸部郭清術式, および治療成績について検討し たので報告する.

\section{対象 と報告}

対象は, 当教室で 1973 年 1 月から 1995 年 6 月まで の 22 年 6 か月間に取り扱った口腔扁平上皮癌一次症 例 274 例のうち, 初回治療として原発巣の切除ととも に頸部郭清術を行った $141 / 274$ 例 (51.5\%) である. その内訳は男性 94 例, 女性 47 例, 平均年齢 61.5 歳で あり，原発部位は舌 $54 / 124$ 例，下顎歯肉 $58 / 78$ 例， 上顎歯肉 $4 / 20$ 例, 口底 $17 / 31$ 例, 㚘粘膜 $6 / 19$ 例, および下顎骨中心 $2 / 2$ 例であった. TNM 分類は， 1987 年 UICC 分類にしたがって行った（Table 1). 
Table 1 Clinical data on neck dissections in 141 patients with primary squamous cell carcinoma of the oral cavity

\begin{tabular}{|c|c|c|c|c|c|c|c|}
\hline & \multirow{2}{*}{$\begin{array}{c}\text { Primary } \\
\text { oral SCC } \\
(n=274)\end{array}$} & \multicolumn{4}{|c|}{ Type of neck dissection } & \multirow{2}{*}{$\begin{array}{c}\text { No. of } \\
\text { neck dissections } \\
(n=141)\end{array}$} & \multirow{2}{*}{$\begin{array}{c}\% \\
\text { undergoing } \\
\text { neck dissection }\end{array}$} \\
\hline & & $\begin{array}{c}\text { RND } \\
(n=65)\end{array}$ & $\begin{array}{l}\mathrm{mRND} \\
(\mathrm{n}=35)\end{array}$ & $\begin{array}{l}\text { SOHND } \\
(\mathrm{n}=1)\end{array}$ & $\begin{array}{l}\text { SHND } \\
(\mathrm{n}=40)\end{array}$ & & \\
\hline \multicolumn{8}{|l|}{ 1. Primary tumor site } \\
\hline Tongue & 124 & $29(1)$ & $19(2)$ & & 6 & $54(3)$ & $43.5 \%$ \\
\hline Lower gingiva & 78 & $20(3)$ & 11 & & $27(1)$ & $58(4)$ & $74.4 \%$ \\
\hline Upper gingiva & 20 & $1(1)$ & 2 & & 1 & $4(1)$ & $20.0 \%$ \\
\hline Floor of the mouth & 31 & $10(3)$ & $2(1)$ & & $5(2)$ & $17(6)$ & $54.8 \%$ \\
\hline Buccal mucosa & 19 & 5 & & 1 & & 6 & $31.6 \%$ \\
\hline Mandible (intraosseous) & 2 & & 1 & & 1 & 2 & $100 \%$ \\
\hline \multicolumn{8}{|l|}{ 2. T-category } \\
\hline $\mathrm{T} 1$ & 95 & $6(2)$ & 3 & & 2 & $11(2)$ & $11.6 \%$ \\
\hline $\mathrm{T} 2$ & 103 & 25 & $16(1)$ & & $21(1)$ & $62(2)$ & $60.2 \%$ \\
\hline T 3 & 17 & 9 & 1 & 1 & 2 & 13 & $76.5 \%$ \\
\hline $\mathrm{T} 4$ & 59 & $25(6)$ & $15(2)$ & & $15(2)$ & $55(10)$ & $93.2 \%$ \\
\hline \multicolumn{8}{|l|}{ 3. N-category } \\
\hline N 0 & 168 & $6(1)$ & $5(1)$ & & $24(2)$ & $35(4)$ & $20.8 \%$ \\
\hline N 1 & 81 & $43(2)$ & 22 & 1 & 15 & $81(2)$ & $100 \%$ \\
\hline $\mathrm{N} 2$ & 21 & $13(4)$ & $7(2)$ & & $1(1)$ & $21(7)$ & $100 \%$ \\
\hline N 3 & 4 & $3(1)$ & 1 & & & $4(1)$ & $100 \%$ \\
\hline \multicolumn{8}{|l|}{ 4. Clinical stage grouping } \\
\hline I & 86 & & & & 2 & 2 & $2.3 \%$ \\
\hline II & 57 & 2 & 2 & & $12(1)$ & $16(1)$ & $28.1 \%$ \\
\hline III & 64 & $32(1)$ & 16 & 1 & 11 & $60(1)$ & $93.8 \%$ \\
\hline IV & 67 & $31(7)$ & $17(3)$ & & $15(2)$ & $63(12)$ & $94.0 \%$ \\
\hline
\end{tabular}

$\mathrm{SCC}=$ squamous cell carcinoma, $\mathrm{RND}=$ radical neck dissection, $\mathrm{mRND}=$ modified $\mathrm{RND}$, $\mathrm{SOHND}=$ supraomohyoid neck dissection, $\mathrm{SHND}=$ suprahyoid neck dissection.

The numbers in parentheses indicate bilateral neck dissection.

当教室で行なった頸部郭清術は, 根治的全頸部郭清 術 (radical neck dissection, 以下 RND), 副神経, 内頸静脈あるいは胸鎖乳突筋のうち 1 つ以上を保存し た全頸部郭清術変法 (modified RND, 以下 mRND), 肩甲舌骨筋上郭清術 (supraomohyoid neck dissection，以下 SOHND），および舌骨上郭清術（suprahyoid neck dissection，以下SHND）である。また, 当教室では原則として子防的頸部郭清（以下尒防郭清） は行っていないが T $4 \mathrm{~N} 0$ 症例，あるいは原発巣切除 時に頸部皮膚切開を加える場合は, SHND による予防 郭清を行っている.

これら 141 例について, 頸部リンパ節の臨床分類 (以下 $\mathrm{N}$ ) と病理学的分類 (以下 $\mathrm{pN}$ ), 郭清術式, 頸部 再発，およびこれらにおける治療成績について検討し， さらに組織学的にリンパ節転移が認められた 71 例に ついては, リンパ節転移の様相についても検討した.

頸部リンパ節領域は, Medina ${ }^{1)}$ による頸部リンパ 節レベル分類に準じて行なった. すなわち, レベル I : オトガイ下・顎下リンパ節, レベルII：上内深頸リン
パ節，レベル III：中内深頸リンパ節，レベル $\mathrm{V}$ ：下内 深頸リンパ節, レベル $\mathrm{V}$ : 後頸部リンパ節の 5 領域で あり, 複数の領域に転移がみられた場合は, 最も進ん だレベルをもって判定した。

治療成績は, Kaplan-Meiyer 法による 5 年累積生 存率にて判定し, 統計学的有意差検定は， $\chi^{2}$ 検定， Wilcoxon 検定およびCox-Mantel 検定を行った。

\section{結果}

\section{$\mathbf{N}$ と $\mathbf{p N}$ について}

これら 141 例のうち, $\mathrm{N} 0$ 症例に対する予防郭清は 35 例であり,このうち $\mathrm{pN}+$ は $11 / 35$ (31.4\%) であっ た。一方, $\mathrm{N}+$ 症例に対する治療的頸部郭清（以下治 療郭清）を行った 106 例のうち, $\mathrm{pN}+$ は $60 / 106$ 例 (56.6\%) であった. 頸部リンパ節転移の正診率を，頸 部リンパ節転移の評価を触診のみで行っていた 1984 年以前, 頸部への CT あるいは MRI が行われるよj になった 1985 年以降, 超音波検査が行われるように 
Table 2 Clinically staged nodes versus pathologically staged nodes

\begin{tabular}{|c|c|c|c|c|c|}
\hline \multirow[b]{2}{*}{$\mathrm{N}$ category } & \multicolumn{4}{|c|}{$\mathrm{pN}$ category } & \multirow[b]{2}{*}{ Total no. } \\
\hline & $\mathrm{pN} 0$ & $\mathrm{pN} 1$ & $\mathrm{pN} 2$ & $\mathrm{pN} 3$ & \\
\hline $\mathrm{No}$ & 24 & 10 & 1 & & 35 \\
\hline $\mathrm{N} 1$ & 41 & 22 & 18 & & 81 \\
\hline N 2 & 5 & & 16 & 2 & 23 \\
\hline N 3 & & & 1 & 1 & 2 \\
\hline \multirow[t]{3}{*}{ Total no. } & 70 & 32 & 36 & 3 & 141 \\
\hline & & $1973-1984$ & $1985-1990$ & 1991-1995 & Total \\
\hline & & $(\mathrm{N}=50)$ & $\begin{array}{c}+\mathrm{CT} / \mathrm{MRI} \\
(\mathrm{N}=37)\end{array}$ & $\begin{array}{l}+ \text { Ultrasound } \\
\quad(\mathrm{N}=54)\end{array}$ & $(\mathrm{N}=141)$ \\
\hline \multicolumn{2}{|c|}{ Correct diagnosis rate } & $58.0 \%$ & $59.5 \%$ & $61.1 \%$ & $59.6 \%$ \\
\hline \multicolumn{2}{|c|}{ Incorrect diagnosis rate } & $42.0 \%$ & $40.5 \%$ & $38.9 \%$ & $40.4 \%$ \\
\hline \multicolumn{2}{|c|}{ False positive rate } & $34.0 \%$ & $32.4 \%$ & $31.5 \%$ & $32.6 \%$ \\
\hline \multicolumn{2}{|c|}{ False negative rate } & $8.0 \%$ & $8.1 \%$ & $7.4 \%$ & $7.8 \%$ \\
\hline
\end{tabular}

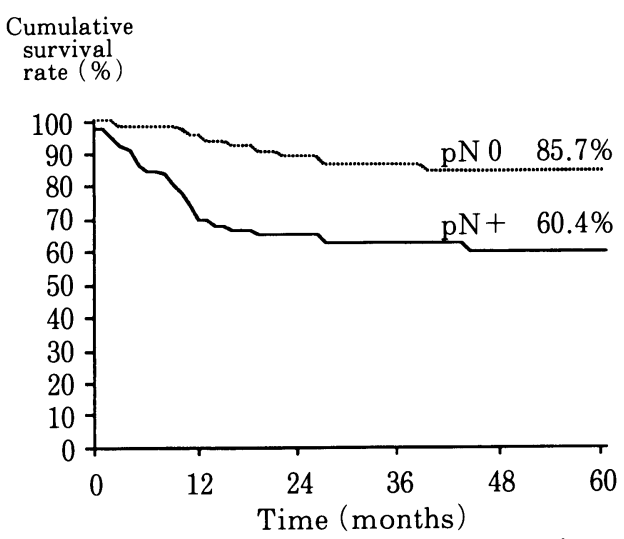

A: Histological neck metastasis

\section{Cumulative \\ survival}

rate (\%)

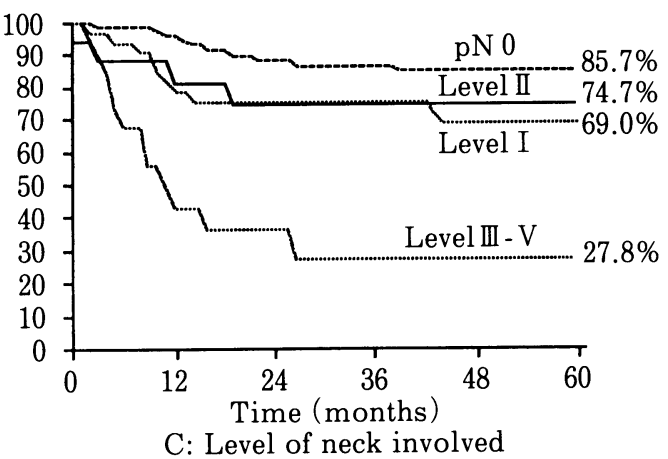

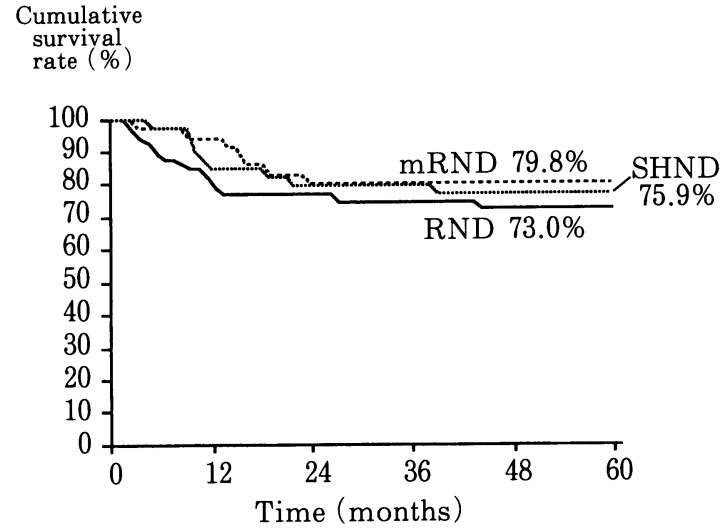

B: Type of neck dissection

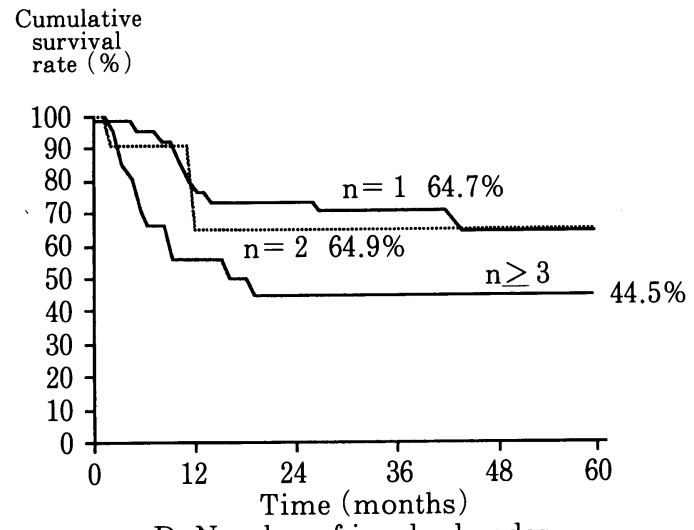

D: Number of involved nodes

Figure 15 -year cumulative survival curves 
Table 3 Failure and recurrence in the neck according to type of neck dissection

\begin{tabular}{|c|c|c|c|c|c|c|c|c|}
\hline & & \multirow[b]{3}{*}{ Total no. } & \multicolumn{4}{|c|}{ Recurrence in the neck } & \multirow{2}{*}{\multicolumn{2}{|c|}{ Failure in the neck }} \\
\hline & & & \multicolumn{2}{|c|}{ ipsilatelal } & \multicolumn{2}{|c|}{ contralateral } & & \\
\hline & & & no. & $\%$ & no. & $\%$ & no. & $\%$ \\
\hline \multirow[t]{4}{*}{$\mathrm{pN} 0:$} & $\mathrm{RND}$ & $28(3)$ & 0 & & 1 & $3.6 \%$ & 1 & $3.6 \%$ \\
\hline & mRND & $15(2)$ & 0 & & 0 & & 0 & \\
\hline & SOHND & 1 & 0 & & 0 & & 0 & \\
\hline & SHND & $26(2)$ & 4 & $15.4 \%$ & 0 & & 2 & $7.7 \%$ \\
\hline \multirow[t]{4}{*}{ pN $1-3:$} & $\mathrm{RND}$ & $37(5)$ & $2(1)$ & $5.4 \%$ & 6 & $16.2 \%$ & 3 & $8.1 \%$ \\
\hline & mRND & $20(1)$ & 2 & $10.0 \%$ & 1 & $5.0 \%$ & 1 & $5.0 \%$ \\
\hline & SHND & $14(1)$ & 2 & $14.3 \%$ & 0 & & $1(1)$ & $7.1 \%$ \\
\hline & Total & 141 & 10 & $6.9 \%$ & 8 & $5.6 \%$ & 8 & $5.6 \%$ \\
\hline
\end{tabular}

$\mathrm{RND}=$ radical neck dissection, $\mathrm{mRND}=$ modified $\mathrm{RND}$,

$\mathrm{SOHND}=$ supraomohyoid neck dissection, $\mathrm{SHND}=$ suprahyoid neck dissection .

The numbers in parentheses indicate bilateral neck dissection.

なった 1991 年以降で比較すると, 諸検査の導入によ り正診率はそれぞれ $58.0 \%, 59.5 \%, 61.1 \%$ 向上傾向 がみられた. CT あるいは MRI の導入により偽陽性率 は $34.0 \%$ から $32.4 \%$ へ低下し, また, 超音波診断の導 入により偽陰性率は $8.1 \%$ から $7.4 \%$ へと低下してい た (Table 2).

頸部郭清施行 141 例の $\mathrm{T}$ と $\mathrm{pN}$ には明らかな相関は なく, $\mathrm{pN} 3$ の 3 例はすべて $\mathrm{T} 1$ 症例であった. 5 年累 積生存率は, $\mathrm{pN} 0$ 群 $85.7 \%, \mathrm{pN}+$ 群 $60.4 \%$ であった $(\mathrm{p}<0.01)$ (Figure 1-A).

\section{郭清術式について}

予防郭清は, SHND が $24 / 35$ 例 $(68.6 \%)$ と最も多 く, 部位では下顎歯肉, 口底, 舌に多かった. 治療郭清 は, RND 59/106 例 (55.7\%), mRND 30/106 例 (28.3\%) であったが, 高齢や合併症のためSHND に とどめた例が $16 / 106$ 例 (15.1\%) にみられた. 両側頸 部郭清が行われた 14 例は，患側 RND + 健側 SHND 7 例, 両側 SHND 3 例, 両側 RND, 患側 $\mathrm{mRND}+$ 健側 RND, 両側 $m R N D$, 患側 mRND+健側 SOHND が 各 1 例であり, 両側 RND 例は患側の頸部郭清の 2 週 間後に健側 RND が行われていた. また, 両側 SHND は口腔前方部に生じた口底癌や下顎歯肉癌に対する予 防郭清として行われていた。

\section{pN 別および郭清術式別にみた頙部再発}

$\mathrm{pN} 0$ 群では, 患側頸部再発はSHND 施行群で $15.4 \%(4 / 26$ 例 $)$ と有意に多く $(\mathrm{p}=0.01)$, 健側頸部 再発は RND 施行群 $3.6 \%$ （1／28 例）にみられ，他で は頸部再発は認めなかった.一方, $\mathrm{pN}+$ 群では, 患側 頸部再発が SHND 施行群 $14.3 \%$ ( $2 / 14$ 例), mRND 施行群 $10.0 \%$ ( $2 / 20$ 例), RND 施行群 5.4\%（2/37 例）とSHND で患側頸部再発が多かった。これに対
して, 健側頸部再発は, RND 施行群 $16.2 \%$ （6/37 例), mRND 施行群 5.0\% (1/20 例), SHND 施行 群 $0 \%$ （0/14 例）とRND 施行群で最も多かった (Table 3). しかしながら，5年累積生存率の郭清術 式による差は認めなかった (Figure 1-B).

\section{䫫部リンパ節への転移様相}

$\mathrm{pN}+71$ 例での転移部位は, レベル I $33 / 71$ 例 (46.5\%), レベル II 18/71 例 $(25.4 \%)$, レベル III 13／ 71 例 $(18.3 \%)$, レベルIV $5 / 71$ 例 $(7.0 \%)$ ，レベル V $2 / 71$ 例 (2.8\%) であった. 原発部位別にみると, 舌, 煩粘膜ではレベル II への転移が多く, 他部位ではレベ ルIへの転移が多かった（Figure 2). また，下顎歯 肉および口底の各 1 例でレベル Vへの転移がみられた。 5 年累積生存率では, レベル III 以上での転移陽性群 27.8\%であり,レベル I 69.0\%おおびレベル II 74.7\% と比して不良であった $(\mathrm{p}<0.01)$ (Figure 1-C).

転移陽性リンパ節数では， 1 個 $37 / 71$ 例 $(52.1 \%)$, 2 個 $12 / 71$ 例 $(16.9 \%)$ ，および 3 個以上 $22 / 71$ 例 (31.0\%) であった. 転移リンパ節数が 3 個以上での 5 年累積生存率は $44.5 \%$ で, それ以下の群と比較して不 良であった (Figure 1-D).

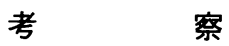

頭頸部扁平上皮癌に対する治療において，頸部リン パ節転移の制御はきわめて重要であり，すでに頸部リ ンパ節転移が明らかな症例に対する根治的な頸部郭清 術は必要不可欠となっている。一方, 臨床的に頸部転 移を捉え得ない段階での予防郭清の適応についてはい まだ確立しておらず, 不必要な侵襲を避けるためにい わゆる “wait and see” が多くの施設で受け入れられ 


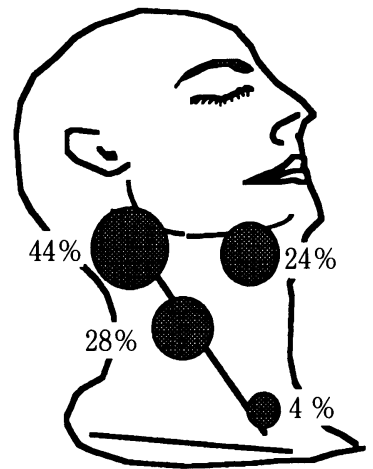

Tongue $(\mathrm{N}=54)$

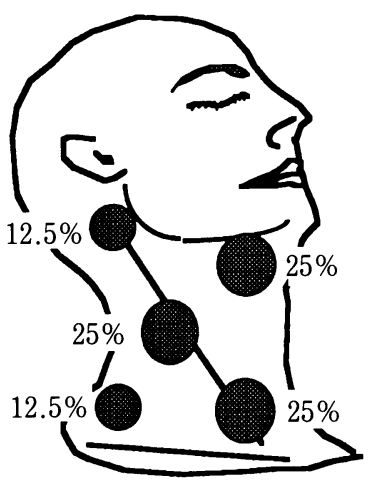

Floor of the mouth $(\mathrm{N}=17)$

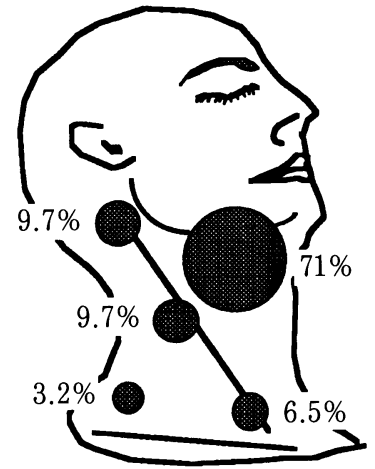

Lower gum $(\mathrm{N}=58)$

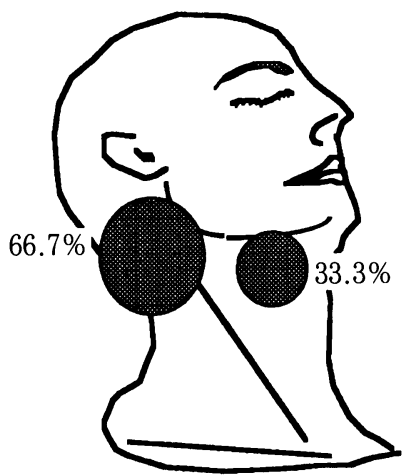

Buccal mucosa $(\mathrm{N}=6)$

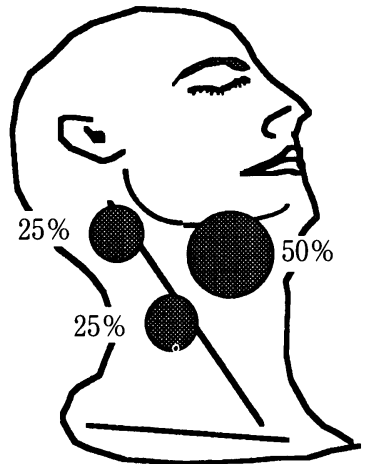

Upper gum $(\mathrm{N}=4)$

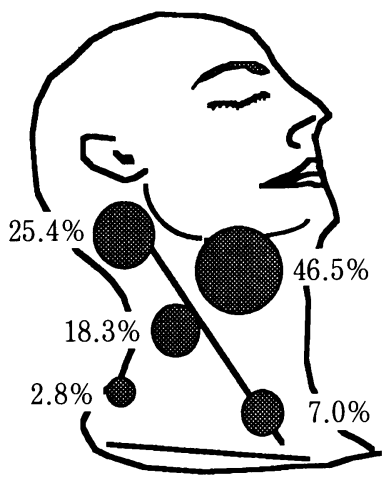

Oral cavity $(\mathrm{N}=139)$

Figure 2 The relative percentage of nodes involved according to the primary tumor site

ている．しかし，後発転移例に対する治療成績が不良 なことから，予防郭清を支持する報告も多い2 5).

予防郭清の必要性を考える場合, その施設での誤診 率は一つの目安となり, Sako ら 6 ) は誤診率 $25 \%$ 以上, Nahum $5^{7)}$ は偽陽性率 40\%以上であれば予防郭清 を行うべきだと述べている. 本検討では, 頸部リンパ 節転移の誤診率は $40.4 \%$, 偽陽性率が $32.6 \%$ と高く, 予防郭清を行うべきとなるが，このように誤診率が高 かった理由として, 1984 年以前は $\mathrm{N}$ の評価は触診の みで行われていたためと考えられる。実際に，諸検査 の導入により誤診率の低下がみられ, 予防郭清を行う 上で特に問題となる偽㓌性率は $7.4 \%$ と低いことから， 当教室では予防郭清は行っていない. しかし, 本来, 予防 郭清は occult metastasis が高い場合に限られるべき であり, Lee ら 8 ) は occult metastasis が $20 \%$ 以上に みられれば予防郭清を支持している. 本検討での頸部 郭清を行った N 0 症例における組織学的転移は $31.4 \%$ (11/35 例) と高頻度であったが, 実際には予防郭清 はおのおのの生物学的悪性度に応じて慎重に行う必要 がある ${ }^{9,10)}$.

原発部位別にみた組織学的転移率は, 下顎歯肉が

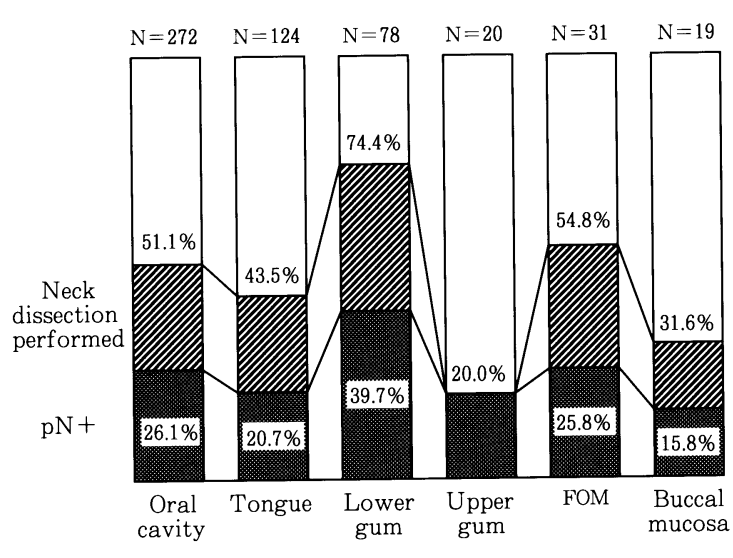

Figure 3 Incidence of neck metastasis in primary squamous cell carcinoma of the oral cavity

$39.7 \%$ と最も高く, 口腔扁平上皮癌の $26.1 \%$ で組織学 的に頸部転移が認められた（Figure 3 ). 下顎歯肉癌 で頸部転移が多いとする報告は多く11,12), 初診時に頸 部転移の多い原発部位と考えられる。 
頸部転移の広がりは, 口腔原発癌では従来の報告と 同様にレベル I，IIに多かった．しかし，口底癌では 全レベルで高頻度に転移が認められ, Shah ら ${ }^{13)}$ も同 様の指摘をしており，口底癌では全レベルの確実な郭 清が必要である.

当教室での郭清方法は, 予防郭清ではSHND を, 治 療郭清では RNDを第 1 選択として行ってきた。 SHND はいまだに予防郭清や健側郭清の際に繁用さ れている術式であるが14,15)，口腔癌での頸部転移はレ ベル I 〜 III多いことから, Donegan ら 16) も SHND の意義を疑問視している. 今回の検討では各郭清法に おいて生存率に差はなかったが, SHND がN 0 に対し て多く行われたことを考慮すると SHND の治療成績 は決して高くない.さらに, SHND を行った 40 例の うち 6 例 $(15.0 \%)$ に同側頸部の郭清範囲外に再発を 認め, うち 3 例 (50\%) は頸部腫場死であった. いづれ も原発巣は制御されており occult metastasis があっ たと考えられ，RND を行うべきであったと反省され る. 本来, 予防郭清はこのような occult metastasis に対して行うべきであり，予防郭清であっても，少な くとも転移の多いレベル I ～IIIまでの郭清, すなわち SOHND を行うべきであり，SHND は姑息的手段と して限定すべきであろう ${ }^{3,4)}$.

一方, 最近では $\mathrm{N}+$ 症例であっても周囲組織との癒 着がなければ努めて副神経あるいは内頸静脈の保存を 図っている. 実際には全頸部郭清を行った 100 例のう ち 35 例 (35.0\%) で mRND が行われており，その内 訳は, 副神経温存 14 例, 内頸静脈温存 15 例, 副神経お よび内頸静脈温存 6 例で, 胸鎖乳突筋を温存した症例 はなかった. RND 群と mRND 群との間には N や臨 床病期による差はなく, 患側頸部再発率ではそれぞれ $3.1 \%$ と $5.7 \%$ と有意な差はなかった。 また, 内頸静脈 の保存のため術後出血などの合併症をきたした経験も ないことから, 領家ら ${ }^{17)}$ も述べるように mRND の貢 献度は高いものと考える。

頸部転移と予後については, Grandi ら ${ }^{18)}$ が遠位レ ベルへの転移や複数個の転移リンパ節があれば予後が 不良であると指摘しているように, 本検討においても 同様にレベル III 以上の転移例や 3 個以上の転移リンパ 節があれば, 生存率は有意に低下していた。

\section{結語}

大学医学部口腔外科学教室 1973 年から 1995 年までに取り扱った口腔扁平上皮癌一次症例 274 例の うち, 初回治療として頸部郭清術を行なった 141 例に ついて検討し以下の結果を得た。

1. 男性 94 例, 女性 47 例, 平均年齢 61.5 歳であり， 原発部位は舌 54 例, 下顎歯肉 58 例, 上顎歯肉 4 例, 口 底 17 例, 煩粘膜 6 例, および下顎骨中心性 2 例であっ
た。

2. 予防郭清は $35 / 141$ 例 $(24.8 \%)$ に行われ，この うち組織学的転移は $11 / 35$ 例 (31.4\%) に認められ， 治療郭清 106 例のうち, 組織学的転移は $60 / 106$ 例 (56.6\%) であった。

3. 頸部リンパ節転移の正診率は $59.6 \%$, 誤診率 $40.4 \%$, 偽陽性率 $32.6 \%$, 偽陰性率 $7.8 \%$ であった。 5 年累積生存率は, $\mathrm{pN} 0$ 群 $85.7 \%, \mathrm{pN}+$ 群 $60.4 \%$ であっ た.

4. 郭清術式は, RND 65 例 (46.1\%), mRND 35 例 (24.8\%), SOHND 1例 (0.7\%), および SHND 40 例 $(28.4 \%)$ であった. 両側頸部郭清は 14 例に行われ ていた. 予防郭清では SHND が $68.6 \%$ と最も多く, 治 療郭清では RND 55.7\%, mRND 28.3\%で, 高齢や合 併症の理由で SHND が $15.1 \% に$ 行われていた. 郭清 術式別の 5 年累積生存率には差は認めなかった.

5 . 患側頸部への再発は SHND 群で郭清範囲外に 多く，健側では RND 群に再発が多かった。

6. 頸部の転移領域は, レベル I $47.2 \%$, レベル II $25.0 \%$, レベル III $18.1 \%$, レベルIV 6.9\%, レベルV 2.8 \%で, レベル I 〜 II几の転移が多かった.下顎歯肉お よび口底の各 1 例でレベル Vへの転移がみられた．5 年累積生存率では, レベル III 以上での転移陽性群 $27.8 \%$ ，レベル I $69.0 \%$ およびレベル II $74.7 \%$ と比し て不良であった。

7. $\mathrm{pN}$ +群の転移陽性リンパ節数は, 1 個 $52.1 \%, 2$ 個 $16.9 \%$ ，および 3 個以上 $31.0 \%$ で， 3 個以上での 5 年累積生存率は $44.5 \%$ であった。

\section{参 考 文 献}

1) Medina, J. E.: A rational classification of neck dissections. Otolaryngol Head Neck Surg 100: 169-176 1989.

2) Martis, C., Karabouta, I., et al.: Incidence of lymph node metastasis in elective (prophylactic) neck dissection for oral carcinoma. J Maxillofac Surg 7 : 182-191 1979.

3) Byers, R.M., Wolf, P.F., et al.: Rationale for elective modified neck dissection. Head Neck Surg 10: 160-167 1988.

4) Medina, J.E. and Byers, R.M.: Supraomohyoid neck dissection: rationale, indications, and surgical technique. Head Neck 11: 111-122 1989.

5) O'Brien, C.J., Lee, K.K., et al.: Comprehensive treatment strategy for oral and oropharyngeal cancer. Am J Surg 164: 582--586 1992.

6) Sako, K., Pradier, P., et al.: Falgility of palpation in the diagnosis of metastases to cervical nodes. Surg Gynecol Obstet 118: 
989-990 1964.

7) Nahum, A.M., Bone, C.R., et al.: The case for elective, prophylactic neck dissection. Laryngoscope 87: 585-599 1976.

8) Lee, J.G., Kraus, C.J., et al.: Radical neck dissection elective, therapeutic and secondary Arch Otolaryngol 101: 656-659 1975.

9) Shingaki, S., Kobayashi, T., et al.: Surgical treatment of stage I and II oral squamous cell carcinomas: analysis of causes of failure. Br J Oral Maxillofac Surg 33: 304-308 1996.

10) Kusukawa, J., Sasaguri, Y., et al.: Expression of matrix metalloproteinase- 3 in stage I and II squamous cell carcinoma of the oral cavity. J Oral Maxillofac Surg 53: 530-534 1995.

11）新垣 晋：口腔領域悪性腫瘍の頸部リンパ節転 移に関する臨床病理学的研究. 日口外誌 34 : 784-797 1988.

12）森山知是, 中澤光博, 他 : 口腔領域扁平上皮癌 患者の転移に関する臨床統計的検討. 第 1 報 : 一次治療時における頸部リンパ節への組織学的
転移陽性例の検討. 口科誌 43: 685-690 1994 .

13) Shah, J.P., Candela, F.C., et al.: The pattern of cervical lymph node metastasis from squamous carcinoma of the oral cavity. Cancer 66: 109-113 1990.

14）矢島幹人, 峯村俊一, 他 : 口腔扁平上皮癌にお ける頸部郭清術施行例の臨床統計的検討. 日口 外誌 35: 647-654 1989 .

15）野谷健一, 井上農夫男, 他 : 当科の頸部廓清例 の検討. 日外誌 32: 602-613 1986 .

16) Donegan, J.O., Gluckman, J.L., et al.: The role of suprahyoid neck dissection in the management of cancer of the tongue and floor of the mouth. Head Neck Surg $4: 209-2121982$.

17）領家和男, 足本 敦, 他：口腔, 上顎洞の扁平 上皮癌に対する内頸静脈, 副神経を保存した頸 部郭清術の治療成績。日口外誌 40: 729-734 1994.

18) Grandi, C., Alloisio, M., et al.: Prognostic significance of lymophatic spread in head and neck carcinomas: therapeutic implication. Head Neck Surg 8: 67-73 1985. 